https://doi.org/10.52058/2786-4952-2022-1(6)-141-150

Гришко Світлана Вікторівна кандидат географічних наук, доцент, завідувач кафедри фізичної географії і геології, Мелітопольський державний педагогічний університет імені Богдана Хмельницького, вул. Гетьманська, 20, м. Мелітополь, 72312, тел.:(0619) 44-04-27, https://orcid.org/0000-0002-5054-3893

Прохорова Лариса Анатоліївна кандидат геологічних наук, доцент доцент, кафедри фізичної географії і геології, Мелітопольський державний педагогічний університет імені Богдана Хмельницького, вул. Гетьманська, 20, м. Мелітополь, 72312, тел.:(0619) 44-04-27, https://orcid.org/0000-0001-7693-1897

Левада Ольга Михайлівна кандидат географічних наук, доцент, доцент кафедри фізичної географії i геології, Мелітопольський державний педагогічний університет імені Богдана Хмельницького, вул. Гетьманська, 20, м. Мелітополь, 72312, тел.:(0619) 44-04-27, https://orcid.org/0000-0003-1476-0089

Непша Олександр Вікторович старший викладач кафедри фізичної географії і геології, Мелітопольський державний педагогічний університет імені Богдана Хмельницького, вул. Гетьманська, 20, м. Мелітополь, 72312, тел.: (0619) 44-04-27, https://orcid.org/0000-0003-3929-9946

Зав'ялова Тетяна Василівна старший викладач кафедри фізичної географії та геології, Мелітопольський державний педагогічний університет імені Богдана Хмельницького, вул. Гетьманська, 20, м. Мелітополь, 72312, тел.: (0619) 44-04-27, https://orcid.org/0000-0002-0040-2611

Іванова Валентина Михайлівна старший викладач кафедри туризму, соціально-економічної географії та краєзнавства, Мелітопольський державний педагогічний університет імені Богдана Хмельницького, вул. Гетьманська, 20, м. Мелітополь, 72312, тел.:(0619) 44-04-27, https://orcid.org/0000-0002-6121-6978

\title{
ЕКОЛОГІЧНЕ ВИХОВАННЯ СТУДЕНТІВ-ГЕОГРАФІВ ПІД ЧАС ВИВЧЕННЯ КУРСУ «ГЕОЛОГІЯ 3 НАВЧАЛЬНОЮ ПРАКТИКОЮ» В ЗАКЛАДІ ВИЩОЇ ОСВІТИ
}

Анотація. Стаття присвячена надзвичайно актуальній темі сьогодні проблемам екологічного виховання майбутніх вчителів географії загальноосвітніх навчальних закладів при вивченні курсу «Геологія 3 навчальною практикою» у педагогічних закладах вищої освіти. Відзначено, що значення геології в суспільстві зростає у зв'язку з необхідністю оцінки стану 
природного середовища, передбачення небезпечних природних геологічних явищ - тобто для вирішення екологічних завдань. Аналіз навчального плану студентів спеціальності 014.07 Середня освіта (Географія) свідчить про те, що основою геологічної педагогічної освіти в Україні $є$ принцип триєдності: геологічна наука - навчання - навчальна практика. Наголошується, що глибока модернізація шкільної та університетської освіти, що обумовлює зміну статусу різних освітніх програм і дисциплін, висуває геологію до дуже важливих знань в освітній стратегії реального майбутнього. При розгляді місця геологічних знань у загальній структурі освіти та завдання розвитку загальної освіченості студентів виявляється, що геологія більш ніж будь-яка інша наука пов'язана з багатьма природничими, технічними та гуманітарними напрямками освіти. Визначено, що вивчення курсу «Геологія 3 навчальною практикою» $\epsilon$ неодмінною основою фундаментальної педагогічної освіти, оскільки дозволяє майбутньому вчителю географії отримати об'єктивні уявлення про будову навколишнього світу, планетарні, регіональні та локальні геологічні процеси, що визначають екологічно безпечну життєдіяльність та природокористування, здійснення технічних проектів. Доведено, що наявність фундаментальних знань із геології дозволить суттєво підвищити професійну компетентність майбутніх учителів географії. В результаті дослідження було визначено, що отримані екологічні знання з раціонального використання та охорони геологічного середовища на лекційних та практичних заняттях у курсі «Геологія з навчальною практикою» дозволять майбутнім вчителям географії застосовувати у їх подальшій педагогічній діяльності у закладах загальної середньої освіти України.

Ключові слова: навчальний курс, екологічна освіта, майбутні вчителі географії, студент-географ, навчальна практика.

Hryshko Svitlana Viktorivna Candidate of Geographical Sciences, Associate Professor, Associate Professor, Head of the Department of Physical Geography and Geology, Bogdan Khmelnitsky Melitopol State Pedagogical University, 72312, Melitopol, Zaporizhzhia region, st. Getmanska, 20, tel.: (0619) 44-04-27, https://orcid.org/0000-0002-5054-3893

Prokhorova Larysa Anatoliivna Candidate of Geological Sciences, Associate Professor, Associate Professor of the Department of Physical Geography and Geology, Bogdan Khmelnitsky Melitopol State Pedagogical University, Getmanska St., 20, Melitopol, 72312, tel.:(0619) 44-04-27, https://orcid.org/0000-0001-7693-1897

Levada Olga Mykhailivna Candidate of Geographical Sciences, Associate Professor, Associate Professor of the Department of Physical Geography and Geology, Bogdan Khmelnitsky Melitopol State Pedagogical University, Getmanska St., 20, Melitopol, 72312, tel.: (0619) 44-04-27, https://orcid.org/0000-0003-1476-0089 
Nepsha Oleksandr Viktorovych Senior Lecturer of the Department of Physical Geography and Geology, Bogdan Khmelnitsky Melitopol State Pedagogical University, Getmanska St., 20, Melitopol, 72312,tel.: (0619) 44-04-27, https://orcid.org/0000-0003-3929-9946

Zavyalova Tetyana Vasylivna Senior Lecturer of the Department of Physical Geography and Geology, Bogdan Khmelnitsky Melitopol State Pedagogical University, Getmanska St., 20, Melitopol, 72312,tel.: (0619) 44-04-27, https://orcid.org/0000-0002-0040-2611

Ivanova Valentyna Mykhailivna Senior Lecturer of the Department of Tourism, Socio-Economic Geography and Local History, Bogdan Khmelnitsky Melitopol State Pedagogical University, Getmanska St., 20, Melitopol, 72312, tel.: (0619) 44-04-27, https://orcid.org/0000-0002-6121-6978

\section{ECOLOGICAL EDUCATION OF STUDENTS-GEOGRAPHERS DURING THE STUDY OF THE COURSE «GEOLOGY WITH EDUCATIONAL PRACTICE» IN A HIGHER EDUCATION INSTITUTION}

Abstract. The article is devoted to the current topic - the problems of environmental education of future teachers of geography of secondary schools in the study of the course «Geology with educational practice» in pedagogical institutions of higher education.

The importance of geology in modern society is growing in connection with the need to assess the state of the natural environment, predict dangerous natural geological phenomena - that is, to solve environmental problems. Analysis of the curriculum of students majoring in 014.07 Secondary education (Geography) shows that the basis of geological pedagogical education in Ukraine is the principle of a trinity: geological science - training - teaching practice. It is emphasized that the deep modernization of school and university education, leading to changes in the status of various educational programs and disciplines, puts geology among the very important knowledge in the educational strategy of the real future. When considering the place of geological knowledge in the general structure of education and the tasks of developing the general education of students, it turns out that geology, more than any other science, is associated with many natural, technical, and humanitarian areas of education. It is determined that the study of the course «Geology with teaching practice» is an essential basis of fundamental pedagogical education, as it allows future geography teachers to get objective ideas about the structure of the world, planetary, regional, and local geological processes that determine environmentally friendly life. It is proved that the availability of fundamental knowledge of geology will significantly increase the professional competence of future teachers of geography. As a result of the study, it was determined that the acquired ecological knowledge on the rational use and 
protection of the geological environment in lectures and practical classes in the course «Geology with teaching practice» will allow future teachers of geography to apply in their further pedagogical activities in general secondary education.

Keywords: training course, environmental education, future teachers of geography, student geography, educational practice.

Постановка проблеми. У сучасному світі проблема екологічного виховання є загальновизнаною. В даний час екологічний напрям в системі професійної освіти в процесі екологічного виховання студентів педагогічних закладів вищої освіти стає помітним фактором, з'являється необхідність інтеграції екологічної та природничої педагогічної освіти: відбувається радикальна зміна ціннісних систем, культурних норм і ідеалів у сучасній молоді, недостатньо розглядаються проблеми формування екологічної культури у студентів педагогічних вишів. Завдання професійної педагогічної освіти - сформувати особистість учителя з високою екологічною культурою, яка прагнула б до оптимальної взаємодії 3 природним середовищем, особистість, що відрізняється наявністю переконань, потребою в діяльності щодо поліпшення навколишнього середовища. Одним з незаперечних фактів при цьому стала необхідність провідної ролі і відповідальності майбутнього вчителя у вирішенні проблем формування екологічної культури у підростаючого покоління, яка здатна сформувати особистість, що відрізняється наявністю переконань дбайливого ставлення до природи. Тому актуальним на соціально-педагогічному рівні стає необхідність посилення уваги до питань формування екологічної культури студентів педвузів майбутніх учителів.

Аналіз останніх досліджень i публікацій. Свої наукові доробки проблемам екологічної освіти та виховання присвятили низка вітчизняних та зарубіжних дослідників, зокрема Л. Білик, Л. Белялова, О. Герасимчук, В. Вернадський, Л. Донченко, Н. Сфименко, В. Іванова, З. Курлянд, І. Звєрєв, О. Мандрик, Л. Лук'янова, В. Петрук, Н. Пустовіт; О. Пруцакова; А. Розсоха, Ю. Саунова, С. Совгіра, І. Суравегіна, В. Сухомлинський, Г. Тамбовцев, Л. Титаренко, О. Федоренко, С. Шмалєй, Г. Ярчук та інші. Дослідження науковців зводяться до наступного: головною метою екологічного виховання $\epsilon$ формування екологічної культури, тобто сукупності екологічно розвинених свідомості, емоційно-чуттєвої діяльності сфер особистості; екологічне виховання виступає сьогодні як пріоритетний напрям розвитку сучасної вищої школи та системи освіти в цілому.

Мета статті - визначити роль і значення курсу «Геологія з навчальною практикою» в екологічному вихованні студентів-географів - майбутніх вчителів географії.

Виклад основного матеріалу. Екологічне виховання та освіта $\epsilon$ неодмінною умовою загального і екологічного розвитку всебічно розвиненої особистості. «Освіта - стратегічна основа розвитку особистості, суспільства, 
нації й держави, запорука майбутнього, найбільш масштабна и людиноємна сфера суспільства, його політичної, соціально-економічної, культурної й наукової організації», - зазначено в Національній доктрині розвитку освіти [14].

Як відзначають у своїх роботах В. Іванова, Я. Сугоняк [4], В. Іванова, Г. Тамбовцев [5], Л. Прохорова та ін. [11], А. Розсоха [12] про те, що екологічне виховання студентів-географів педагогічних закладів вищої освіти передбачає цілеспрямоване формування особливого стилю мислення екологічного, в якому суспільство і природа $є$ ланками одного системи, функціонуючи в тісному взаємозв'язку i доповнюючи один одного. Порушення балансу в цій системі як раз і призводить до негативних наслідків.

У контексті наведеної інформації слушною $є$ думка О. Мандрик, М. Мальованого, М. Орфанової про те, що «Екологічна освіта має бути тривалим та міждисциплінарним за своєю суттю процесом, вивчати основні проблеми навколишнього середовища, надавати можливість молоді застосовувати свої знання та допомогти учням розглядати навколишне середовище в усій його повноті» [9].

Аналіз науково-педагогічної літератури $[1,3,8,15]$ дозволив визначити, те, що при реалізації екологічного виховання студентів закладів вищої освіти (3ВО) необхідно керуватися наступними завданнями:

- формування наукової основи уявлень про функціонування системи «людина-природа», що дає можливість зрозуміти механізм роботи цієї системи з точки зору екологічної доцільності;

- розвиток навичок і умінь по взаємодії людини 3 природою 3 раціональної точки зору;

- популяризація екологічних знань 3 метою залучення все більшої кількості зацікавлених осіб;

- розвиток особистісної мотивації в раціональному ставленні до природи;

- залучення студентів до роботи з охорони природи шляхом організації різних заходів екологічного спрямування (суботники, розробка екологічних стежок, екологічні квести, озеленення територій) та ін.

На сучасному етапі розвитку суспільства людство стоїть на межі глобальної екологічної кризи, антропогенне навантаження на природні ландшафти настільки велика, що багато негативні процеси запущені вже є незворотнім. Людиною освоєно більше половини поверхні суші, за рік з надр землі витягується близько 100 млрд. тонн мінеральної сировини, близько 600 млрд. тонн промислових стоків забруднюють поверхневі і підземні води. Разом 3 прискореними темпами зростання населення планети збільшуються його потреби в ресурсах, енергії, харчуванні і т. ін. [7]. Тому стає важливим здійснювати екологічне виховання на всіх етапах становлення особистості людини.

За визначенням екологічне виховання полягає у формуванні у людей дбайливого ставлення до навколишнього середовища, яке спрямоване на 
Журнал«Герспективита іновації наукиљ

(Серія«Гедагогіка»), Серія«ГТихологія», Серія«Медицинв»

№1(6) 2022

охорону і раціональне використання природних ресурсів. Геологія - одна 3 дисциплін фізико-географічного блоку наук, основним об'єктом вивчення якої $\epsilon$ Земля, а значить, в ході освоєння цієї дисципліни неминуче зачіпаються теми, пов’язані з дбайливим (раціональним) ставленням, наприклад, до надр Землі і не тільки. Геологія - наука комплексна, одним 3 іiі відгалужень $\epsilon$ екологічна геологія - відносно новий напрямок, яке займається вивченням екологічних функцій літосфери, закономірностей ऑiі формування i просторово-часових змін під впливом в основному техногенних причин.

У Мелітопольському державному педагогічному університеті імені Богдана Хмельницького курс «Геологія 3 навчальною практикою» викладається студентам I курсу спеціальності 014.07 Середня освіта (Географія) у I-II семестрах в обсязі 240 годин (8 кредитів ECTS). В даному курсі формуються уявлення про єдність природи і суспільства, розвиваються вміння оцінювати навантаження на геологічне середовище від видобутку корисних копалин, розвивається почуття особистої відповідальності за стан навколишнього середовища.

Екологічне виховання в ході вивчення геології здійснюється в кілька етапів:

I етап - студенти знайомляться 3 основними екологічними проблемами, пов'язаними 3 геологічними процесами, вивчають механізми їх розвитку, поширення.

II етап - оцінюють екологічні наслідки цих процесів, ступінь тяжкості їх прояви в різних регіонах.

III етап - прогнозують подальший розвиток подій і пропонують шляхи оптимізації. В результаті у студентів формується чітке уявлення про проблему в цілому та шляхи іï вирішення, зростає свідомість і особиста мотивація до раціонального (екологічному) відношенню до природи.

Існує велика кількість екологічних проблем, пов'язаних з геологічними процесами і використанням надр землі, які вивчаються в курсі «Геологія 3 навчальною практикою»:

1. Виснаження запасів мінеральних ресурсів. Більшість видів мінеральної сировини відноситься до невідновлюваних, процес їх формування зайняв мільйони років, наприклад, вугленосні товщі сформувалися близько 350-280 млн. років тому, поклади крейди -145-65 млн. років тому. Це говорить про те, що нові поклади якщо і сформуються, то людство навряд чи зможе ними скористатися.

2. Мінеральна сировина видобувається 3 надр різними способами, які найчастіше призводять до значних перетворень поверхні Землі. Кар'єрним (відкритим) способом видобувають, наприклад, алмази, різні руди та ін. Як результат, на поверхні Землі залишаються антропогенні негативні форми рельєфу, що порушують екологічну рівновагу і псують естетичне сприйняття ландшафтів. Питання рекультивації кар'єрів і териконів саме на часі останнім часом, пропонується маса різних рішень: використання їх в якості об'єктів 
туризму, облаштування гірськолижних трас, озеленення невибагливими видами рослинності.

3. Видобуток нафти йде шляхом викачування, в результаті на глибині залишаються величезні пустоти, згодом в цих місцях можуть виникати провали на поверхні, що призводять до руйнувань i порушують природні ландшафти. Крім того, іноді бувають аварії на платформах, які видобувають нафту, або танкерах, що перевозять іiі, що призводить до розливу нафти i забруднення територій.

4. При видобутку сипких корисних копалин або їх дробленні (пісок, мергель, вапняки та ін.) В повітря піднімається величезна кількість пилу, що знижує прозорість атмосфери, що розсіює сонячну радіацію, а значить, що порушує тепловий баланс поверхні і забруднює атмосферу твердими частинками.

5. Родовища отруйних або радіоактивних корисних копалин, а також тверді, погано розчинні відходи, що утворюються при видобутку, наприклад, кам'яної солі (по 3-4 тонни на тонну солі), розмиваючись атмосферними опадами, можуть потрапляти в наземні і підземні води, а звідти до людей i викликати отруєння.

6. Вітер i вода $є$ руйнівними геологічними силами, вони ведуть колосальну роботу по переміщенню пухких гірських порід, це призводить до здування поверхневого шару грунту, виникнення пилових бур, ерозії i, як наслідок, утворення ярів. Землі втрачають родючість, виникають так звані бедленди, отримання з них хорошого врожаю стає проблематичним.

7. Видобуток корисних копалин призводить до зміни рівня підземних вод i виснаження поверхневих. Наприклад, при видобутку вугілля відкачують підземні води поблизу родовища, в результаті чого виникають депресивні воронки, зникають джерела і т. ін.

Вивчення цих явищ в курсі геології супроводжується розбором їх негативних наслідків, локалізації екологічних проблем. Тут добре зарекомендував себе метод проектів. Працюючи над матеріалом в ході створення проекту, студенти глибоко переймаються даними проблемами, у них формується особистісна мотивація щодо дотримання принципів раціонального природокористування. Пропонуючи шляхи рекультивації кар'єрів, териконів, студенти безпосередньо беруть участь у вирішенні екологічних проблем. Крім отримання еколого-геологічних знань, йде ще й екологічне виховання, так як при вивченні негативних наслідків деяких геологічних процесів мало хто залишається байдужим.

Екологічне виховання $є$ також невід'ємною частиною навчальної практики з геології. Студенти, вивчаючи геологічну будову Запорізької області в польових умовах, бачать, яка гарна природа оточує їх, вчаться любити iіi i оберігати [2, 6, 11]. При здійсненні польових досліджень, які полягають в копанні шурфів, бурінні, зборі геологічних зразків, необхідно проводити всі вишукування акуратно, не завдаючи шкоди навколишньому середовищу i, по можливості, 3 мінімальним пошкодженням поверхні. Всі шурфи після 
вивчення акуратно закопуються, відновлюється природний покрив [13].

Висновки. Таким чином, ми бачимо, що питання екологічного виховання зараз дуже актуальне. Екологічне виховання студентів $є$ невід'ємною частиною формування гармонійно розвиненої особистості, і здійснювати його необхідно в рамках всіх дисциплін. Велика роль екологічного виховання відводиться при вивченні курсу геології в педагогічних закладах вищої освіти, тут формується уявлення про планету Земля як цілісну систему, всі оболонки якої пов'язані між собою, і порушення в якийсь із них може призвести до незворотних змін. Вивчаються екологічні наслідки, пов'язані з геологічними процесами, розробляються шляхи вирішення екологічних проблем, i, звичайно ж, прищеплюється любов до природи і природних ресурсів, їх раціонального використання.

\section{Лimepamypa:}

1. Герасимчук О.Л. Екологічне виховання в контексті сучасної парадигми сталого розвитку. Інноваційні підходи до виховання студентської молоді у вищих навчальних закладах: матеріали Міжнар. наук.-практ. конференції (м. Житомир, 22-23 травня 2014 р.). Житомир: Вид-во ЖДУ ім. І. Франка, 2014. С. 401-406.

2. Данильченко О., Корнус О., Корнус А., Сюткін С., Нешатаєв Б. Практична підготовка студентів: стан і проблеми // Проблеми безперервної географічної освіти i картографії. 2018. Вип. 27. С. 28-34.

3. Донченко Л.М. Виховання екологічної культури студентів 3 ВО в контексті гуманізації університетської освіти: матеріали II Міжнародної науково-практичної інтернетконференції «II Шкловські читання «Проблеми сучасних природничо-математичних наук та методик їх викладання». Глухів, 2020. С. 221.

4. Іванова В., Сугоняк Я. Шляхи формування екологічного світогляду та екологічної культури майбутніх вчителів географії. Розвиток сучасної освіти і науки: результати, проблеми, перспективи. Інтердисциплінарні виміри / редактори-упорядники: Я. Гжесяк, І.Зимомря, В. Ільницький. Конін - Ужгород - Херсон - Кривий Ріг: Посвіт, 2019. С. 223-225.

5. Іванова В.М., Тамбовцев Г.В. Формування екологічної культури майбутніх учителів географії в процесі вивчення дисциплін фізико-географічного циклу. Актуальные научные исследования в современном мире. Переяслав-Хмельницький, 2019. Вып. 11(55), ч. 6. С. 91-96.

6. Іванова В.М., Шелудько О.М. Навчальна практика з геології як умова формування екологічної компетентності майбутніх вчителів географії. Наукове сьогодення: теоретикоприкладні дослідження та перспективи: матеріали Всеукраїнської науково-практичної конференції (м. Мелітополь, 17 травня 2019 року). Мелітополь: Вид-во МДПУ імені Богдана Хмельницького, 2019. С. 20-22.

7. Екологічна геологія: підручник. / за ред. д. г.-м. н. М.М. Коржнева. Київ: ВПЦ «Київський університет», 2005. 257 с.

8. Екологічне виховання студентської молоді: Педагогіка вищої школи / авт.-укл.: 3.Н. Курлянд. К.: Знання, 2007. 495 с.

9. Мандрик О.М., Мальований М.С., Орфанова М.М. Екологічна освіта та екологічне виховання // Екологічна безпека та збалансоване ресурсокористування. Науково-технічний журнал. 2019. № 1(19). С. 130-139.

10. Прохорова Л.А., Гришко С.В., Непша О.В., Зав'ялова Т.В. Педагогічні умови формування екологічної культури майбутніх учителів географії під час вивчення дисциплін професійного циклу // Інноваційна педагогіка. 2021. Вип. 34. Т. 2. С. 181-186.

11. Прохорова Л.А., Гришко С.В., Непша О.В. Екологічний зміст навчальної практики 
3 геології та геоморфології географів-бакалаврів. Географія та туризм: матеріали IV Всеукраїнської науково-практичної Інтернет-конференції Харківського національного педагогічного університету ім. Г.С. Сковороди (м. Харків, 26 лютого 2021 р.). Харків: ХНПУ ім. Г.С. Сковороди, 2021. С. 26-31.

12. Розсоха А.П. Формування екологічної культури у майбутніх учителів географії. Молодий учений. 2016. № 9.1(36.1). С. 138-142.

13. Стецишин М.M., Непша О.В., Кондратенко А.І. Вивчення фізико-геологічних та антропогенних процесів на навчальній практиці з геології в Північно-Західному Приазов'ї. Гуманітарний простір науки: досвід та перспективи: матеріали V Міжнарод. наук. практ. інтернет-конф. (м. Переяслав-Хмельницький, 20 вересня 2016 р.). ПереяславХмельницький, 2016. Вип. 5. С. 14-18.

14. Указ Президента України «Про Національну доктрину розвитку освіти». № 347/2022 від 17.04.2002 p. https://zakon4.rada.gov.ua/laws/show/347/2002.

15. Ярчук Г. Екологічне виховання: сутність та основні напрями. Вища освіта України. 2008. № 2. С. 91-97.

\section{References:}

1. Herasymchuk O.L. (2014). Ekolohichne vykhovannia v konteksti suchasnoi paradyhmy staloho rozvytku [Environmental education in the context of the modern paradigm of sustainable development]. Innovatsiini pidkhody do vykhovannia studentskoi molodi u vyshchykh navchalnykh zakladakh: materialy Mizhnar. nauk.-prakt. konferentsii (m. Zhytomyr, 22-23 travnia 2014 r.). Zhytomyr: Vyd-vo ZhDU im. I. Franka. S. 401-406 [in Ukrainian].

2. Danylchenko O., Kornus O., Kornus A., Siutkin S., Neshataiev B. (2018). Praktychna pidhotovka studentiv: stan i problemy [Practical training of students: state and problems]. Problemy bezperervnoi heohrafichnoi osvity i kartohrafii. Vyp. 27, S. 28-34 [in Ukrainian].

3. Donchenko L.M. (2020). Vykhovannia ekolohichnoi kultury studentiv ZVO v konteksti humanizatsii universytetskoi osvity [Education of ecological culture of students of HEI in the context of humanization of university education]: materialy II Mizhnarodnoi naukovo-praktychnoi internet-konferentsii «II Shklovski chytannia «Problemy suchasnykh pryrodnychomatematychnykh nauk ta metodyk yikh vykladannia». Hlukhiv. S. 221 [in Ukrainian].

4. Ivanova V., Suhoniak Ya. (2019). Shliakhy formuvannia ekolohichnoho svitohliadu ta ekolohichnoi kultury maibutnikh vchyteliv heohrafii [Ways of forming ecological worldview and ecological culture of future geography teachers]. Rozvytok suchasnoi osvity i nauky: rezultaty, problemy, perspektyvy. Interdystsyplinarni vymiry / redaktory-uporiadnyky: Ya. Gzhesiak, I. Zymomria,V. Inytskyi. Konin - Uzhhorod - Kherson - Kryvyi Rih: Posvit. S. 223-225 [in Ukrainian].

5. Ivanova V.M., Tambovtsev H.V. (2019). Formuvannia ekolohichnoi kultury maibutnikh uchyteliv heohrafii v protsesi vyvchennia dystsyplin fizyko-heohrafichnoho tsyklu [Formation of ecological culture of future teachers of geography in the process of studying the disciplines of the physical-geographical cycle]. Aktual'nye nauchnye issledovaniya $\mathrm{v}$ sovremennom mire. Pereyaslav-Khmel'nic'kij. Vyp. 11(55). ch. 6, S. 91-96 [in Ukrainian].

6. Ivanova V.M., Sheludko O.M. (2019). Navchalna praktyka z heolohii yak umova formuvannia ekolohichnoi kompetentnosti maibutnikh vchyteliv heohrafii [Educational practice in geology as a condition for the formation of environmental competence of future teachers of geography]. Naukove sohodennia: teoretyko-prykladni doslidzhennia ta perspektyvy: materialy Vseukrainskoi naukovo-praktychnoi konferentsii (m. Melitopol, 17 travnia 2019 roku). Melitopol: Vyd-vo MDPU imeni Bohdana Khmelnytskoho. S. 20-22 [in Ukrainian].

7. Ekolohichna heolohiia [Ecological geology]: pidruchnyk (2005). / za red. d. h.-m. n. M.M. Korzhneva. Kyiv: VPTs «Kyivskyi universytet». 257 s. [in Ukrainian].

8. Ekolohichne vykhovannia studentskoi molodi: Pedahohika vyshchoi shkoly (2007). [Ecological education of student youth: Higher school pedagogy] / avt.-ukl.: Z.N. Kurliand. K.: 
Znannia. 495 s. [in Ukrainian].

9. Mandryk O.M., Malovanyi M.S., Orfanova M.M. (2019). Ekolohichna osvita ta ekolohichne vykhovannia [Environmental education and environmental education] // Ekolohichna bezpeka ta zbalansovane resursokorystuvannia. Naukovo-tekhnichnyi zhurnal. № 1(19), S. 130-139 [in Ukrainian].

10. Prokhorova L.A., Hryshko S.V., Nepsha O.V., Zavialova T.V. (2021). Pedahohichni umovy formuvannia ekolohichnoi kultury maibutnikh uchyteliv heohrafii pid chas vyvchennia dystsyplin profesiinoho tsyklu [Pedagogical conditions of formation of ecological culture of future teachers of geography during studying of disciplines of a professional cycle] // Innovatsiina pedahohika. Vyp. 34, T. 2, S. 181-186 [in Ukrainian].

11. Prokhorova L.A., Hryshko S.V., Nepsha O.V. (2021). Ekolohichnyi zmist navchalnoi praktyky $\mathrm{z}$ heolohii ta heomorfolohii heohrafiv-bakalavriv [Ecological content of educational practice in geology and geomorphology of geographers-bachelors]. Heohrafiia ta turyzm: materialy IV Vseukrainskoi naukovo-praktychnoi Internet-konferentsii Kharkivskoho natsionalnoho pedahohichnoho universytetu im. H.S. Skovorody (m. Kharkiv, 26 liutoho 2021 r.). Kharkiv: KhNPU im. H.S. Skovorody. S. 26-31 [in Ukrainian].

12. Rozsokha A.P. (2016). Formuvannia ekolohichnoi kultury u maibutnikh uchyteliv heohrafii [Formation of ecological culture in future teachers of geography]. Molodyi uchenyi. № 9.1(36.1), S. 138-142 [in Ukrainian].

13. Stetsyshyn M.M., Nepsha O.V., Kondratenko A.I. (2016). Vyvchennia fizykoheolohichnykh ta antropohennykh protsesiv na navchalnii praktytsi $\mathrm{z}$ heolohii $\mathrm{v}$ PivnichnoZakhidnomu Pryazovi [Study of physico-geological and anthropogenic processes in educational practice in geology in the North-Western Pryazovia]. Humanitarnyi prostir nauky: dosvid ta perspektyvy: materialy V Mizhnarod. nauk. prakt. internet-konf. (m. Pereiaslav-Khmelnytskyi, 20 veresnia 2016 r.). Pereiaslav-Khmelnytskyi. Vyp. 5, S. 14-18 [in Ukrainian].

14. Ukaz Prezydenta Ukrainy «Pro Natsionalnu doktrynu rozvytku osvity» : vid 17.04.2002, № 347/2022 [Law of Ukraine «On the National Doctrine of Education Development» from April 17, 2002, № 347/2022]. (n.d.). president.gov.ua. Retrieved from https://zakon4.rada.gov.ua/laws/ show/347/2002 [in Ukrainian].

15.Iarchuk H. (2008). Ekolohichne vykhovannia: sutnist ta osnovni napriamy [Environmental education: essence and main directions]. Vyshcha osvita Ukrainy. № 2, S. $91-97$ [in Ukrainian]. 